\title{
ANALISIS SELISIH BIAYA TENAGA KERJA LANGSUNG PT. HAGANAMO MANDIRI
}

\author{
Nitema Gulo ${ }^{1)}$, Selamat Zebua ${ }^{2)}$ \\ ${ }^{1,2}$ Dosen Fakultas Ekonomi dan Bisnis Universitas Raharja \\ nitema@raharja.info, selamat.zebua@raharja.info
}

\begin{abstract}
Abstrak
Dalam perkembangan industri saat ini selalu mengikuti perkembangan teknologi, tetapi juga industri tidak terlepas dari penggunaan biaya tenaga kerja langsung, sehingga suatu perusahaan dapat tercapai suatu tujuan untuk mendapatkan laba yang maksimal. biaya tenaga kerja langsung merupakan biaya yang dikeluarkan oleh suatu perusahaan untuk memproduksi suatu barang atau jasa. Penelitian bertujuan untuk bisa mendapatkan informasi yang akurat dalam pelaksanaan suatu kegiatan apakah terjadi kekeliruan antara biaya tenaga kerja langsung standar pada biaya tenaga kerja langsung sesungguhnya. Metode penelitian yang digunakan adalah kualitatif dengan metode analisis, sehingga peneliti bisa mengetahui perbedaan biaya tenaga kerja langsung yang telah ditetapkan di awal produksi pada biaya tenaga kerja yang sesungguhnya.
\end{abstract}

Kata Kunci : Biaya Tenaga Kerja Langsung.

\begin{abstract}
In today's industrial development, it always follows technological developments, but the industry cannot be separated from the use of direct labor costs, so that a company can achieve a goal to get maximum profit. Direct labor costs are costs incurred by a company to produce a good or service. The research aims to be able to obtain accurate information in the implementation of an activity whether there is a mistake between standard direct labor costs and actual direct labor costs. The research method used is qualitative with the method of analysis, so that researchers can find out the difference in direct labor costs that have been determined at the beginning of production in real labor costs.
\end{abstract}

Keywords: Direct Labor Costs.

\section{Pendahuluan}

Menghadapi rivalitas terhadap perusahaan domestik maupun perusahaan asing, setiap perusahaan menerapkan manajemen yang sangat baik agar tidak terjadi penyimpangan dalam perusahaan terutama dalam biaya. Selisih (variance) biaya standar dari biaya sesungguhnya adalah penyimpangan Megawati et al, (2016). Setiap perusahaan harus dapat mempertahankan kondisi perusahaan, dengan membuat sistem manajemen yang lebih baik sehingga dapat membuat kebijakan dan keputusan yang dapat meningkatkan omset yang tinggi pada suatu perusahaan. Suatu perusahaan banyak yang melakukan kegiatan tanpa mempertimbangkan biaya, bahkan jauh dari prediksi biaya awal sehingga perusahaan dapat mengalami kerugian bahkan kebangkrutan. Maka dari itu, peran manajemen biaya yang rigid merupakan kunci utama sebab kerangka manajemen bisa membuat evaluasi pada biaya yang telah dikeluarkan oleh perusahaan. Dalam suatu 
perusahaan, biaya tenaga kerja langsung merupakan komponen yang sangat penting dalam perusahaan. Tenaga kerja juga memegang peranan penting dalam perusahan karen jalannya suatu perusahaan tergantung pada tenaga kerja langsung atau karyawan. jadi biaya tenaga kerja langsung salah satu peranan penting untuk mencapai laba yang lebih tinggi. Oleh sebab itu manajemen harus mampu untuk mengolah dan menganalisis terutama dalam pengendalian, perencanaan, membuat keputusan, informasi dan mampu mengendalikan suatu keadaan. Pengendalian yang dilakukan pada biaya tenaga kerja langsung dengan membandingkan biaya yang telah ditentukan oleh perusahan dengan biaya yang sesungguhnya, sehingga dapat melihat apakah terjadi selisih dan apakah selisih tersebut membuat perusahaan mengalami kerugian atau keuntungan. Oleh sebab itu, perumusan masalah adalah bagaimana perhitungan biaya standar yang diterapkan pada PT. Haganamo Mandiri?, apakah terjadi penyimpangan terhadap biaya sesungguhnya dengan biaya tenaga kerja langsung standar?, dan bagaimana menganalisis penyimpangan biaya sesungguhnya dengan biaya standar?

\section{Landasan Teori}

Biaya standar salah satu pedoman dalam manajemen untuk menjalankan kegiatan tertentu, dan juga melakukan pengurangan biaya terutama dalam produksi (Mulyadi dalam Rubiyanto, 2019). Biaya standar merupakan pengeluaran dalam kegiatan tertentu dalam waktu yang telah ditentukan atau memproduksikan suatu barang dan jasa (Halim dalam Panggabean, et al 2016). Sedangkan biaya sesungguhnya yang telah dikeluarkan oleh suatu perusahaan dengan perhitungan lebih awal pembiayaan yang dikeluarkan adalah biaya standar. Jadi, biaya standar adalah pedoman dalam manajemen untuk membiayai suatu kegiatan pada waktu tertentu yang telah ditentukan sebelumnya. Suatu kegiatan yang dilakukan secara langsung oleh pihak yang terkait dalam memproduksi barang dan jasa. Biaya tenaga kerja merupakan jasa yang diterima oleh seseorang atau diterima ketika telah melakukan suatu kegiatan berdasarkan kesepakatan kedua belah pihak. Mendefinisikan bahwa biaya tenaga kerja adalah biaya yang dibayarkan kepada pengguna jasa (Mulyadi dalam Tukasno 2017). Sedangkan menurut Sukirno (2008:6) biaya tenaga kerja adalah hak yang diterima setiap orang yang ada dalam perusahan untuk melakukan suatu kegiatan secara tidak langsung maupun secara langsung.

Biaya Standar memiliki prosedur penentuan dengan tiga hal, yakni: a) Biaya tenaga kerja standar, yaitu biaya tenaga kerja langsung untuk memproduksi suatu barang dan jasa merupakan pengertian biaya tenaga kerja standar. biaya tenaga kerja standar terdiri dari tarif upah standar dan jam tenaga kerja standar. b) Biaya Bahan Baku Standar, merupakan biaya untuk membuat suatu produk dari bahan baku menjadi barang jadi, yang terdiri dari kualitas bahan baku standar dan harga bahan baku standar. c) Biaya Overhead Pabrik Standar, yaitu Biaya overhead pabrik standar menganggarkan jumlah biaya pada kapasitas normal dengan menghitung jumlah biaya overhead pabrik seperti harga standar dan jam standar

\section{Analisis Biaya Standar dari Penyimpangan Biaya Sesungguhnya}

Selisih (variance) biaya standar dari biaya sesungguhnya dikatakan penyimpangan, (Mulyadi dalam Novadilla 2017). Penyimpangang dari biaya standar pada biaya sesungguhnya dilakukan analisis untuk mengetahui selisih biaya tersebut dan mencari solusi agar tidak terjadi kerugian dalam perusahaan. penyebab utamanya adalah seperti, kerusakan peralatan, libur nasional, karyawan sakit dan seterusnya, yang mengakibatkan terjadinya kenaikan biaya yang telah ditentukan dari awal. Untuk biaya overhead pabrik berbeda dengan menganalisis biaya tenaga kerja dan selisih bahan baku, sehingga analisis biaya standar dari penyimpangan biaya sesungguhnya. untuk mengetahui selisih tersebut 
maka, ada dua analisis yang kita gunakan adalah, yang pertama analisis selisih biaya overhead pabrik, yang kedua analisis biaya produksi langsung seperti biaya tenaga kerja langsung dan biaya bahan baku langsung.

\section{Analisis Selisih Biaya Tenaga Kerja langsung}

Selisih biaya tenaga kerja langsung Adalah selisih yang disebabkan oleh adanya perbedaan antara biaya tenaga kerja langsung standar dengan yang sesungguhnya terjadi. Terdapat tiga model selisih yaitu:

\section{Dengan satu selisih}

Untuk menghitung satu selisih yang perlu diperhatikan adalah penggabungan selisih efisiensi dengan selisih tarif. Dengan rumus :

$$
S U=(T s t \times J K s t) \quad(T s s \times J K s s)
$$

\section{Dengan Dua Selisih}

Untuk menghitung dengan dua selisih merupakan biaya standar pada biaya sesungguhnya dengan memperhatikan efisiensi upah langsung pada tarif. dengan rumus :

$$
\begin{array}{cc}
S T=(T s t & T s s) x J K s s \\
S E=(J K s t & J K s s) \times T s t
\end{array}
$$

\section{Dengan Tiga Selisih}

Dengan tiga selisih pada biaya sesungguhnya biaya standar. untuk hal tersebut yang diperhatikan adalah selisih tarif, dan selisih efisiensi. itu bisa terjadi karena kemungkinan jam kerja standar dan tarif lebih kecil dengan biaya sesungguhnya. Sehingga terjadi jam kerja standar dan tarif standar lebih kecil dengan jam kerja sesungguhnya dan tarif sesungguhnya. dengan rumus :

$$
\begin{aligned}
& S T=\left(\begin{array}{ll}
T s t & T s s
\end{array}\right) \times \mathrm{Jst} \\
& S E=(J K s t \quad J K s s) x T s t \\
& S T E=\left(\begin{array}{ll}
T s t & T s s
\end{array}\right) x(J K s t \quad J K s s)
\end{aligned}
$$

Dengan jam kerja sesungguhnya dan tarif sesungguhnya lebih rendah dengan jam kerja standar dan tarif standar. dengan rumus :

$$
\begin{aligned}
& S T=\left(\begin{array}{ll}
T s t & T s s
\end{array}\right) \times J k t \\
& S E=(J K s t \quad J K s s) \times T s t \\
& S T E=(T s t \quad T s s) x(J K s t \quad J K s s)
\end{aligned}
$$

Dengan jam kerja sesungguhnya lebih kecil dari jam kerja standar sementara tarif sesungguhnya lebih tinggi dengan tarif standar. dengan rumus :

$$
\begin{array}{cc}
S T=(T s t & T s s) \times J K s t \\
S E=(J K s t & J K s s) \times T s t
\end{array}
$$

Dengan demikian maka, efisiensi upah dengan selisih tarif adalah nol

Sehingga, jam kerja sesungguhnya lebih besar dengan jam kerja standar begitu juga dengan tarif sesungguhnya lebih renda dengan tarif standar. dengan rumus :

$$
\begin{array}{cc}
S T=\left(\begin{array}{ll}
T s t & T s s) \times J K s t \\
S E=(J K s t & J K s s) \times T s t
\end{array}\right.
\end{array}
$$


Dengan pemakain rumus tersebut maka, $\mathbf{L}$ dengan menandai selisih laba, $\mathbf{R}$ menandai selisih rugi. dengan perhitungan tersebut dapat mengetahui terjadinya selisih.

\section{Metodologi Penelitian}

Analisis data menggunakan deskriptif adalah salah satu metode penelitian kualitatif, yang menekankan pada makna dan proses dengan data yang didapat dilapangan sesuai dengan kebutuhan peneliti. Menurut Wahyuni, T. (2015, August) dalam Sugiyono, bahwa penelitian kualitatif dengan instrumen paling penting dalam menganalisis data sehingga hasil penelitian dapat dipahami dan membuat kesimpulan dalam proses penelitian dengan hasil yang didapat. laporan penelitian atau hal yang sudah ada dalam penelitian merupakan penelitian deskriptif, menurut Wahyuni, T. (2015, August) dalam Suharsimi Arikunto. Dengan pengumpulan data studi pustaka, observasi dan wawancara berkaitan penelitian kemudian menganalisis data dan mengolah sehingga bisa dipahami dan dimengerti permasalahan yang terjadi dalam penelitian. kesimpulan dari suatu penelitian biasa dijadikan tolak ukur dalam pengambilan keputusan.

\section{Pembahasan}

Data Biaya Tenaga Kerja Pada PT. Haganamo Mandiri

Dalam menjalankan operasinya PT. Haganamo Mandiri mempekerjakan 29 orang karyawan dengan biaya tenaga kerja langsung untuk bagian produksi. PT. Haganamo Mandiri mempunyai aturan dalam biaya tenaga kerja langsung.

\section{a) Penentuan Jam Kerja}

Penentuan jam kerja standar yang berlaku pada PT. Haganamo Mandiri adalah 8 jam / hari adalah dengan rincian waktu :

- Senin sampai hari jumat mulai jam delapan pagi sampai setengah lima sore

- Jam kerja selanjutnya dan hari libur (Sabtu,Minggu Hari libur nasional) Disebut lembur, yang diatur dengan ketentuan yang ditetapkan perusahaan.

Berikut adalah data jam kerja yang berlaku dari bulan Juli 2016 - Desember 2016 :

Tabel 1. Penentuan jam kerja PT. Haganamo Mandiri Juli 2016 - Desember 2016

\begin{tabular}{|l|l|}
\hline Bulan & Jumlah jam Kerja normal \\
\hline Juli & 160 \\
\hline Agustus & 168 \\
\hline September & 168 \\
\hline October & 160 \\
\hline November & 176 \\
\hline Desember & 168 \\
\hline
\end{tabular}

Sumber: PT. Haganamo Mandiri

Pada tabel 1 diatas menunjukkan bahwa Pengurai jam kerja mulai dari bulan Juli Desember 2016. Sedangkan jam kerja terendah terdapat pada bulan juli dan oktober disebabkan adanya hari libur nasional, sementara jam kerja paling tinggi terdapat pada bulan November disebabkan karena memenuhi pesanan sehingga PT. Haganamo Mandiri menambahkan jam kerja dengan sistem lembur karyawan. 
b) Penentuan Biaya Upah Standar

Biaya upah yang ditetapkan oleh PT. Haganamo Mandiri yang dibayarkan kepada karyawan adalah sebagai berikut :

- Upah per jam Rp. 13.750.

- Upah harian Rp. 13.750 x 8 jam = Rp. 110.000 / hari

- Upah lembur karyawan mempunyai ketentuan sebagai berikut :

Upah lembur $=2$ x Rp. $13.750=\operatorname{Rp} 27.500$

Perhitungan Biaya Tenaga Kerja Langsung Standar

PT. Haganamo Mandiri memberikan standar biaya tenaga kerja langsung terlihat pada tabel 2 berikut :

Tabel 2. Biaya Tenaga Kerja Langsung Standar PT. Haganamo Mandiri 2016

\begin{tabular}{|l|l|l|l|l|l|l|l|}
\hline \multicolumn{1}{|c|}{ Bulan } & $\begin{array}{c}\text { Tenaga } \\
\text { Kerja }\end{array}$ & $\begin{array}{c}\text { Jam } \\
\text { norma } \\
\mathbf{l}\end{array}$ & $\begin{array}{c}\text { Lembu } \\
\mathbf{r}\end{array}$ & $\begin{array}{c}\text { Standa } \\
\mathbf{r}\end{array}$ & $\begin{array}{c}\text { Jumlah } \\
\text { Jam } \\
\text { Kerja }\end{array}$ & $\begin{array}{c}\text { Total } \\
\text { Standa } \\
\mathbf{r}\end{array}$ & $\begin{array}{c}\text { Total Biaya } \\
\mathbf{( R p )}\end{array}$ \\
\hline & $\mathbf{1}$ & $\mathbf{2}$ & $\mathbf{3}$ & $\mathbf{2 + 3 = 4}$ & $\mathbf{1 * 2 = 5}$ & $\mathbf{6}$ & $\mathbf{5 * 6 = 7}$ \\
\hline Juli & 29 & 160 & 2 & 162 & 4.640 & 13.750 & 63.800 .000 \\
\hline Agustus & 29 & 168 & 2 & 170 & 4.872 & 13.750 & 66.990 .000 \\
\hline September & 29 & 188 & 2 & 170 & 4.872 & 13.750 & 66.990 .000 \\
\hline Oktober & 29 & 160 & 2 & 162 & 4.640 & 13.750 & 63.800 .000 \\
\hline November & 29 & 176 & 2 & 178 & 5.104 & 13.750 & 70.180 .000 \\
\hline Desember & 29 & 168 & 2 & 170 & 4.872 & 13.750 & 66.990 .000 \\
\hline Total & & $\mathbf{1 . 0 0 0}$ & $\mathbf{1 2}$ & $\mathbf{1 . 0 1 2}$ & $\mathbf{2 9 . 0 0 0}$ & & $\mathbf{3 9 8 . 7 5 0 . 0 0 0}$ \\
\hline
\end{tabular}

Pada tabel 2 diatas menunjukkan bahwa total jam kerja dari keseluruhan dari bulan julidesember 201629.000 jam kerja sementara total biaya tenaga kerja langsung standar sebesar RP 398.750 .000

Faktor - faktor yang mendasari penentuan jam kerja standar tersebut diatas diantaranya adalah :

1. Memperhitungkan penambahan jumlah jam kerja karena adanya pesanan dari luar.

2. Memperhitungkan penentuan berlakunya jam lembur.

\section{Perhitungan Biaya Tenaga Kerja Langsung Sesungguhnya}

PT. Haganamo Mandiri melakukan perhitungan biaya tenaga kerja langsung ketika telah memproduksi produknya, sehingga memperoleh besar Biaya Tenaga Kerja Langsung yang aktualnya.

Tabel 3. Perhitungan biaya tenaga kerja langsung sesungguhnya PT.

Haganamo Mandiri

\begin{tabular}{|c|c|c|c|c|c|c|c|c|c|c|}
\hline & $\begin{array}{l}\text { Tenaga } \\
\text { Kerja }\end{array}$ & $\begin{array}{l}\text { Jumlah } \\
\text { Jam } \\
\text { Normal }\end{array}$ & $\begin{array}{l}\text { Jumlah } \\
\text { Jam } \\
\text { Lembur }\end{array}$ & Jam ss & Jum J.ss & $\begin{array}{l}\text { Jum } \\
\text { Lb }\end{array}$ & T.Lb & Tot. U. Lb & Tot. U. Lb & Tot BI \\
\hline Bulan & 1 & 2 & 3 & $2+3=4$ & $1 * 4=5$ & $1 * 3=6$ & 7 & $6 * 7=8$ & 9 & $8+9=10$ \\
\hline Juli & 29 & 160 & 4 & 164 & 4.756 & 116 & 27.500 & 3.190 .000 & 63.800 .000 & 66.990 .000 \\
\hline Agustus & 29 & 168 & 27 & 195 & 5.655 & 783 & 27.500 & 21.532 .500 & 66.990 .000 & 88.522 .500 \\
\hline September & 29 & 168 & 6 & 174 & 5.046 & 174 & 27.500 & 4.785 .000 & 66.990 .000 & 71.775 .000 \\
\hline Oktober & 29 & 160 & 8 & 168 & 4.872 & 232 & 27.500 & 6.380 .000 & 63.800 .000 & 71.180 .000 \\
\hline November & 29 & 176 & 2 & 178 & 5.162 & 58 & 27.500 & 1.595 .000 & 70.180 .000 & 71.775 .000 \\
\hline Desember & 29 & 168 & 5 & 173 & 5.017 & 145 & 27.500 & 3.978 .500 & 66.990 .000 & 70.977 .500 \\
\hline Total & & 1.000 & 52 & 1.052 & 30.508 & & & 41.470 .000 & $\begin{array}{l}\text { 398.750.00 } \\
\text { 0 }\end{array}$ & $\begin{array}{l}440.220 .00 \\
0\end{array}$ \\
\hline
\end{tabular}


Pada tabel 3 diatas menunjukkan bahwa total biaya kerja langsung sesungguhnya adalah sebesar Rp 440.220.000 disebabkan karena penambahan total upah lembur dengan total upah standar.

$$
\begin{gathered}
\text { Tarif Upa Sesunggu nya }=\frac{\text { Total Biaya Sesung gu nya }}{\text { Jumla Jam Sesunggu nya }} \\
\text { Tarif Upa Sesunggu nya }=\frac{R p 440.220 .000}{30.508} \\
\text { Tarif Upa Sesung } \\
\text { nya }=R p 14.429,65779
\end{gathered}
$$

\subsection{Perhitungan Selisih Biaya Tenaga Kerja Langsung}

PT. Haganamo Mandiri telah mendapatkan data tentang biaya tenaga kerja langsung sesungguhnya dan biaya tenaga kerja langsung standar diperoleh, maka perhitungan selisih biaya tenaga kerja langsung dapat dilakukan. Dalam menghitung selisih tersebut penelitian menggunakan metode tiga selisih. Dalam metode tiga selisih, dengan biaya yang terjadi sesungguhnya antara biaya yang distandarkan. dengan cara, yaitu selisih tarif, efisiensi dan tarif efisiensi.

\section{a. Selisih Tarif}

Diketahui :

$$
\begin{array}{ll}
\text { Tst } & =13.750 \\
\text { Tss } & =14.429,65779
\end{array}
$$

Jadi, tarif sesungguhnya lebih tinggi dengan tarif standar JKst $\quad=29.000$ jam

Dengan menggunakan rumus :

$$
\text { Maka : }
$$

$$
S T=\left(\begin{array}{ll}
T s t & T s s
\end{array}\right) x J K s t
$$

$$
\begin{aligned}
& S T=\left(\begin{array}{cc}
T s t & T s s
\end{array}\right) \times \mathrm{JKst} \\
& S T=(R p 13.750 \quad R p 14.429,65779) \times 29.000 \mathrm{Jam} \\
& S T=679,65779 \times 29.000 \mathrm{Jam} \\
& S T=R p 19.710,075
\end{aligned}
$$

\section{b. Selisih Efisien}

Diketahui :

$$
\begin{array}{ll}
\text { JKst } & =29.000 \mathrm{jam} \\
\text { JKss } & =30.508 \mathrm{jam} \\
\text { Tst } & =\mathrm{Rp} .13 .750
\end{array}
$$

Jadi, jam kerja sesungguhnya lebih tinggi dengan jam kerja standar Dengan menggunakan rumus :

Maka :

$$
S E=(J K s t \quad J k s s) x T s t
$$

$$
\begin{aligned}
& S E=(J K s t \quad J k s s) \times T s t \\
& S E=(29.000 \mathrm{Jam} \quad 30.508 \mathrm{Jam}) \times R p 13.750 \\
& S E=1.508 \mathrm{Jam} \times R p 13.750 \\
& S E=R p R p 20.735 .000(R)
\end{aligned}
$$

\section{c. Selisih Tarif Efisiensi}

$$
\begin{aligned}
\text { Diketahui : } & \text { Tst }=\text { Rp. } 13.750 \\
\text { Tss } & =\text { Rp. } 14.429,65779 \\
\text { JKst } & =29.000 \mathrm{jam} \\
\text { JKss } & =30.508 \mathrm{jam}
\end{aligned}
$$

Dengan menggunakan rumus :

$$
S T E=\left(\begin{array}{ll}
T s t & T s s) x(J K s t \\
J K s s
\end{array}\right)
$$


Maka :

$$
\begin{aligned}
& S T E=(T s t \quad T s s) x(J K s t \quad J K s s) \\
& S T E=\left(\begin{array}{lll}
R p 13.750 & R p 14.429,65779) \times(29.000 \mathrm{Jam} & 30.508 \mathrm{Jam}
\end{array}\right) \\
& S T E=R p 679,65779 \times 1.508 \mathrm{Jam} \\
& S T E=R p 1.024 .429,39(R)
\end{aligned}
$$

Setelah kita menghitung selisih maka biasa kita mencari jumlah tarif efisiensi dan selisih tarif

Dapat Dirumuskan Dengan :

Maka :

$$
\text { Selisih BTKL }=S T+S E+S T E
$$

$$
\begin{aligned}
\text { Selisi } \quad B T K L & =S T+S E+S T E \\
& =\mathrm{Rp} 19.710,075(\mathrm{R})+\mathrm{Rp} 20.735 .000(\mathrm{R})+\mathrm{Rp} 1.024 .492,39(\mathrm{R}) \\
& =\mathrm{Rp} 41.469,567(\mathrm{R}) \\
\text { Pembulatan } & =\mathbf{4 1 . 4 7 0 . 0 0 0 , 0 0 ( R )}
\end{aligned}
$$

\begin{tabular}{|c|c|c|c|c|c|c|c|c|c|}
\hline Bulan & $\begin{array}{l}\text { Tarif } \\
\text { Standar }\end{array}$ & $\begin{array}{l}\text { Tarif } \\
\text { Sesungguhnya }\end{array}$ & $\begin{array}{l}\text { Jumlah } \\
\text { Jam } \\
\text { Standar }\end{array}$ & $\begin{array}{l}\text { Jumlah } \\
\text { Jam } \\
\text { Sesungg } \\
\text { uhnya }\end{array}$ & $\begin{array}{l}\text { Tarif } \\
\text { Standar- } \\
\text { Tarif } \\
\text { Sesungguh } \\
\text { nya }\end{array}$ & $\begin{array}{l}\text { Jama } \\
\text { kerja } \\
\text { standar- } \\
\text { jam kerja } \\
\text { sesunggu } \\
\text { hnya }\end{array}$ & $\begin{array}{l}\text { Selisih } \\
\text { Tarif }\end{array}$ & $\begin{array}{l}\text { Selisih } \\
\text { Efisiensi }\end{array}$ & $\begin{array}{l}\text { Selisih Tarif } \\
\text { Efisiensi }\end{array}$ \\
\hline & 1 & 2 & 3 & 4 & $1-2=5$ & $3-4=6$ & $5 \times 3=7$ & $6 \times 1=8$ & $5 \times 6=9$ \\
\hline Jul & 13.750 & $14.429,65779$ & 4.640 & 4.756 & 679,65779 & 116 & 3.153 .612 & 1.153 .000 & $78.840,030$ \\
\hline Agt & 13.750 & $14.429,65779$ & 4.872 & 5.655 & 679,65779 & 783 & 3.311 .292 & 10.766 .250 & $502.072,204$ \\
\hline Sep & 13.750 & $14.429,65779$ & 4.872 & 5.046 & 679,65779 & 174 & 3.311 .292 & 2.392 .500 & $108.160,072$ \\
\hline Okt & 13.750 & $14.429,65779$ & 4.640 & 4.872 & 679,65779 & 232 & 3.153 .612 & 3.190 .000 & $107.280,045$ \\
\hline Nov & 13.750 & $14.429,65779$ & 5.104 & 5.162 & 679,65779 & 58 & 3.468 .973 & 797.500 & $39.420,015$ \\
\hline Des & 13.750 & $14.429,65779$ & 4.872 & 5.017 & 679,65779 & 145 & 3.311 .292 & 1.993 .750 & $95.050,037$ \\
\hline TOTAL & & & 29.000 & 30.508 & & 1.508 & 19.710 .073 & 20.735 .000 & $1.108 .323,647$ \\
\hline
\end{tabular}

Mencari selisih Biaya tenaga kerja Langsung sesungguhnya dengan Biaya Tenaga Kerja Langsung standar

Dapat Dirumuskan Dengan :

Maka :

$$
\text { Selisih BTKL = BTKL Standard BTKL Sesungguhnya }
$$

$$
\text { Selisi } \begin{aligned}
B T K L & =\text { BTKL Standard BTKL Sesunggu nya } \\
& =\operatorname{Rp} 398.750 .000-\mathrm{Rp} 440.220 .000 \\
& =\operatorname{Rp} 41.470 .000(\mathbf{R})
\end{aligned}
$$

Tabel 4. Perhitungan Selisih Biaya Tenaga Kerja Langsung PT. Haganamo Mandiri

Pada tabel 4 diatas menunjukkan bahwa selisih tarif, selisih efesiensi dan selisih tarif efesiensi disebabkan karena penentuan biaya standar oleh PT.Haganamo Mandiri.

\section{Analisis Selisih Biaya Tenaga Kerja Langsung}

Berdasarkan perhitungan diatas, maka adanya penyimpangan dengan biaya sesungguhnya sebesar Rp. 41.470 .000 disebabkan oleh :
a. Selisih tarif sebesar Rp 19.710.075
b. Selisih Efisiensi Sebesar Rp 20.735.000
c. Selisih Tarif Efisiensi Sebesar Rp 1.024.492,39

Penyebab adanya penyimpangan dalam hal selisih tarif, selisih efisiensi dan selisih tarif efisiensi tersebut adalah :

a. Adanya ketidak efisienan dengan merekrut tenaga kerja baru.

b. Adanya hal diluar kontrol manajemen seperti karyawan sakit, mesin rusak.

c. Adanya kesalahan dalam penentuan kapasitas ( jam ) standar. 
d. Disebabkan bagian produksi tidak efisien dalam menentukan upah langsung.

\section{Kesimpulan}

Dari pembahasan diatas maka dapat disimpulkan bahwa

a. Perhitungan biaya standar yang diterapkan oleh PT. Haganamo Mandiri mengalami selisih disebabkan karena adanya jam lembur karyawan.

b. Biaya tenaga kerja langsung PT. Haganamo Mandiri tidak terjadi penyimpangan, tetapi mengalami selisih biaya karena faktor lain misalnya, ada penambahan pesanan, karyawan sakit.

c. Setelah melakukan Analisis maka tidak terindikasi penyimpangan biaya sesungguhnya dengan biaya standar PT. Haganamo Mandiri tetapi mengalami selisih biaya sebesar Rp. 41.470 .000 (R), disebabkan karena adanya pesanan khusus dari luar, Izin cuti karyawan, dimana untuk penggantian karyawan yang tidak hadir tersebut perusahaan harus menambah jumlah jam kerjanya dan adanya hari libur nasional khususnya lebaran, dimana karyawan yang bekerja pada hari tersebut dikategorikan lembur.

\section{DAFTAR PUSTAKA}

Anugrah, R. E. (2019). Analisis Penerapan Anggaran Sebagai Alat Pengendalian Biaya Dan Pengukuran Kinerja Pada Pt. Pelabuhan Indonesia I (Persero) Cabang Terminal Petikemas Domestik Belawan (Doctoral dissertation, Universitas Islam Negeri Sumatera Utara).

Megawati, D. L., Saifi, M., \& Zahroh, Z. A. (2016). Analisis Perhitungan Biaya Standar Sebagai Salah Satu Pendukung Efisiensi Biaya Produksi (Studi Pada Koperasi Serba Usaha Brosem Batu Pada Tahun 2015). Jurnal Administrasi Bisnis, 38(1), 97-105.

Megawati, D. L., Saifi, M., \& Zahroh, Z. A. (2016). Analisis Perhitungan Biaya Standar Sebagai Salah Satu Pendukung Efisiensi Biaya Produksi (Studi Pada Koperasi Serba Usaha Brosem Batu Pada Tahun 2015). Jurnal Administrasi Bisnis, 38(1), 97-105.

Novadilla, L. (2017). Analisis Varians Biaya Bahan Baku Dan Biaya Tenaga Kerja Langsung Terhadap Biaya Standar Untuk Meningkatkan Laba Usaha Konveksi Outfix-Outfit Di Kota Malang (Doctoral dissertation, Universitas Brawijaya).

Panggabean, R. B., Hamidi, H., \& Salesti, J. (2016). Analisa biaya standar dan pengendalian biaya tenaga kerja langsung pada pt. Drydocks world paxocean di kota batam. Measurement: Jurnal Akuntansi, 10(2).

Rubiyanto, R. (2019). Analisis varian biaya standar dengan biaya aktual untuk menilai efisiensi dan efektivitas anggaran perusahaan CV. Karya bersama dlanggu mojokerto (Doctoral dissertation, Universitas islam majapahit).

Tukasno, T. (2017). Pengaruh Biaya Bahan Baku Dan Biaya Tenaga Kerja Terhadap Volume Produksi Tungku Di Desa Braja Mulya Kecamatan Braja Selebah. Journal Dinamika STIE Lampung, 3(2), 25-36.

Wahyuni, T. (2015, August). Analisis Biaya Standar Sebagai Alat Pengendalian Biaya Produksi Pada CV. IJO. In FIPA: Forum Ilmiah Pendidikan Akuntansi (Vol. 3, No. 2). 